This seems to me to be the immediate objective to work for, since if it can be attained the other secondary troubles which affect the scientist will in large measure fall away. These troubles, refusals of passports and visas, secrecy of scientific work, lack of freedom to publish (with its bad consequences for the individual trying to change his job), are things that really hurt scientists. We have a big job to do upholding the decencies of our profession and trying in all ways open to us to maintain the international unity of science against those influences that are trying to stifle it. But $I$ think it is an illusion to suppose that ours is more than a delaying action; a delaying action which only makes sense on the supposition of an end by international agreement to the war preparations.

My own view about improving international relations and opening the way towards such an agreement is that the best hope lies in recognizing how firmly nationalist feeling is entrenched in the world to-day. My travels have extended only from the Alps to the Arctic Ocean and from Poland to Ireland, but even within that narrow compass there is plenty of nationalism, and it does not seem to be associated with any particular system of government or religion. To advocate a balanced national economy and truly reciprocal trading relations with other nations is not an inspiring doctrine compared with ambitious schemes for world or continental federation, international plans for reconstruction, and so forth. But I cannot help feeling that it is the path for true internationalism at the present time, and that these more grandiose proposals are very often suspect as projects for veiled interference by foreigners in a nation's own affairs. In particular, I think it is highly indiscreet for citizens of Britain to preach to other nations, particularly Asiatic nations, the neoMalthusianism that has recently become so fashionable. Two members of the Committee of Science for Peace, F. le Gros Clark and N. W. Pirie, have done an excellent job in bringing together a number of gifted authorities on food ${ }^{2}$ to show that these are problems for the coming two generations. It is for us to ensure their survival in an undamaged world. With them, we can all express our gratitude to Lord Boyd Orr for his evangelism for food and his respect for humanity all over the world.

While working towards really effective international agreement, we could well take steps to put our own national affairs in order. It has not been convincingly shown that even under existing conditions a smaller military expenditure could not be used to ensure more effectively our national security. At the same time, tensions due to the presence of our forces in the territory of other nations could be relaxed. We could also assert our sovereignty in our external trade, make suitable long-term trade agreements and keep them scrupulously. Such measures would permit at least the beginning of a departure from being chronically on the brink of bankruptey, as well as contributing substantially to a diminution of international tension. We could then set about some of the jobs that are crying out to be done. Foremost of these is to stop cutting the education of our children. Of all the various forms of poundfoolishness in which we are involved at the moment this seems to me the one that will have the worst results in the long run. But we could also make a start on the long overdue improvements in most of our industrial capital equipment, and particularly in our use of fuel. Agriculture could also absorb a lot of capital with advantage. Once a government could show that it had some faith in the future, stemmed the inflation and produced a standard of living that rose rather than fell, plenty of people would be ready to put savings into productive projects of this kind. So far as scientists are concerned we have at this moment, with our tradition of all-sided fundamental science, a magnificent basis for developing those newer branches of technology that will be needed. New branches of pure science will also need cultivation. We have rather a good reserve of trained people who could do with wider scope for their abilities. We might even have a few over for helping other nations should they ask for such help.

Very few of the matters $I$ have been discussing concern scientists alone. But progress on all of them would be more rapid if scientists were more upstanding and vocal about them; if, in fact, they took a more serious view of their responsibilities.

1 Science for Peace, 49 Flower Lane, London, N.W.7.

" "Four Thousand Million Mouths", ed. F. le Gros Clark and N. W. Pirie (Oxford University Press)'.

\section{RESEARCH DEVELOPMENT IN THE MACHINE-TOOL INDUSTRY OF THE U.S.S.R.}

$\mathrm{T}$ an editorial in the Russian machine and tool journal, Stanki $i$ Instr. $(24$ (1), 1 ; 1953), which is the official organ of the U.S.S.R. Ministry of Machine Construction, a directive is quoted of the nineteenth Session of the All Union Party on the progress of the current five-year plan (1951-55) as follows: "[Among our immediate objectives are] to improve the work of the scientific research institutes and the scientific labours of the highest scholastic establishments; make fuller use of the powers of science to solve fundamental questions in development of the national economy ; make more generally available the most advanced engineering practice; and ensure wider practical use of scientific discoveries; moreover, to assist in every way the teaching profession to work out their theoretical problems in all branches of knowledge, and to strengthen the union of science with industry".

In the report on the work of the Central Committee of the Communist Party of the Soviet Union (VKP), Mr. Malenkov is quoted as emphasizing that, in the struggle for further technical progress, science must play a much greater part. Only thus will the Soviet people more fully discover and better utilize the great wealth and powerful forces of Nature. Much success has been already achieved in recent years of the greatest importance in the Soviet economy. At the same time, he revealed also certain defects and weaknesses. Incidentally, it may be observed that, at the eighteenth Session of the Party, Malenkov had a great deal to say by way of censure for slackness and bad management in certain branches of industry (quoted in a recent issue of the journal of the glass and ceramic industry, Steklo $i$ Keramika).

The editorial proceeds to exemplify this closer union of research and industry by a brief review of the work of the various institutes associated with the Ministry of Machine Construction. Among these are : the Experimental Scientific Research Institute for Metal-cutting Machines (ENIMS), the Scientific 
Reserrch Institute for Tools (VNII), and the Scientific Research Institute for Abrasives and Grinding (VNIIASH). The relevant branches of manufacture receive regularly from these and other establishments information and examples of products and processes whereby labour efficiency can be raised, metalworking and the like improved, etc. Special attention is given to mechanization and automatization of methods. In addition to the three technical institutes mentioned, there is also a fourth which appears to fulfil the functions of a standardizing office, this being the Bureaiu of Interchangeability (BV). A great part of the work of all is concerned with components for electric motors and for the automobile and tractor industries, with formulating the best types of mass-production lines and working cycles, and in developing new machines and mothods generally.

More specifically, the Abrasives and Grinding Institute has established the conditions for producing abrasive particles of given qualities and characteristics whereby grinding and polishing can be much more accurately controlled than was hitherto possible. Further details of its work were given in a report on the Russian abrasives industry (Stanki $i$ Instr., 23 (12), 6 ; December 1952). Reference is made to a large number of different types of new machines, tools and instruments, supplied to various factories in 1951 and 1952, including some woodworking and foundry equipment by the respective institutes for these two branches of industry. Details with drawings of some of these were published in Stanki $i$ Instr. during 1952.

Yet it is complained that the introduction of new methods and improved equipment proceeds much too slowly, at all events in some of the engineering works, and there is considerable room for speeding-up and more efficient management in this direction. The same criticism has been noted in other industriesfor example, in some of the glass and ceramic factories-according to the official journal for these. As has been stated above, it was voiced by Malenkov at the eighteenth Session of the Party in 1951. For example, some of the comparatively new designs from the metal-cutting machines institute, evolved five or six years ago, for high-efficiency worm-gear modular milling machines, permitting rates of feed two or three times greater than hitherto, have only very tardily been adopted ("become familiar") in general practice. More particularly in the machine construction works, the results of research, including now and improved types of high-efficiency gearcutting machines, undertaken by the tool research institute and the Novo-Kramatorsk heavy machinetool factory of the Ministry, have been practically ignored.

The improved ceramic-tipped or -faced cuttingtools designed by the abrasives institute, more especially those with thermo-corundum tips, should be much more widely adopted. These tools can replace those of high-speed steel and hard metals very often to great advantage both in high finish and semi-finish work, and thus ensure considerable economy in tungsten, titanium, cobalt and other materials in short supply. The real fault sometimes may lie with the institute concerned and its associate works, for, although it appears a little ambiguous, the statement is made to the effect that the abrasives institute, for example, together with the principal abrasive factory (Glavabraziva), produce totally inadequate supplies of high-speed grinding wheels (this, of course, may be partly due to lack of demand), and the metal-cutting mochines institute is also charged with slackness in production.

It is suggested that, for speeding-up the more general adoption of better methods and equipment, the institutes concerned must maintain closer liaison with the factories, from the very beginning of their research along any particular line. This should be to the mutual advantage of both sides. More especially the workers themselves in the factories should be interested in, and attracted to, new developments. (Incidentally, it may be mentioned that one means of doing this in the machine-tool industry, to which reference is made from time to time in the technical press, is the organization of prize competitions for improved machine designs, although these may be limited mainly to the higher ranks of foremen, managers and draughtsmen.)

The scientific research establishments are directed to make wider use of possibilities suggested to them in the instructions and directives issued by the Ministry of Machine Construction. These directives apply also to the factories, and charge them with definite responsibilities in regard to the introduction of results obtained in the research institutes. It is a binding obligation on every worker, both in the institutes and in the factories, to make the fullest use of such results, described as the most powerful aid towards further engineering progress.

$$
\text { W. G. CASS }
$$

\section{TRANSFERASE ACTIVITY OF HYDROLYTIC ENZYMES}

\author{
By DR. R. K. MORTON
}

School of Biochemistry, University of Cambridge*

$\mathrm{N}$ recent years there have been a number of experimental demonstrations that certain preparations of hydrolytic enzymes may catalyse the formation of new compounds by transfer of a group from a 'donor' compound to $a$ suitable 'acceptor'. While this 'transferase' activity was found to be associated with certain preparations of $\beta$-glycosidases ${ }^{1}$, proteinases $^{2}$, and acid ${ }^{3,4}$ and alkaline $\theta^{5}$ phosphatases, the relationship between the enzymes catalysing hydrolysis and transfer was by no means clear. The exchange reaction has been ascribed to the combined action of two enzymes ${ }^{1}$ to specific transferring enzymes ${ }^{4}$ and to the hydrolases themselves ${ }^{2,3,5}$. A detriled study of the action of highly purified alkaline phosphatase has therefore been carried out in this laboratory. The results, which are summarized in this article, indicate the probable mechanism of the exchange reactions. They have been briefly reported elsewhere ${ }^{\mathrm{B}}$.

\section{Transfer Reactions catalysed by Alkaline Phosphatase}

The alkaline phosphatases of both cow's milk and calf intestinal mucosa were purified to obtain essentially electrophoretically homogeneous proteins, using procedures already briefly described in Nature? Synthetic creatine phosphate, glucose, magnesium acetate, and veronal buffer were incubated with the purified enzyme at $p \mathrm{H} 9 \cdot 6$ and at $37^{\circ} \mathrm{C}$. for $2-5 \mathrm{~min}$.

* Present address: Department of Biochemistry, University of Melbourne. 